\title{
Out-of-pile performance of High Temperature Irradiation Resistant and Cladding Thermocouples
}

Richard Skifton, Lance Hone, Joe Palmer ${ }^{1}$ Ember Sikorski, Scott Riley, Brian Jaques, Lan $\mathrm{Li}^{2}$

${ }^{1}$ Idaho National Laboratory ${ }^{2}$ Boise State University

August 2019

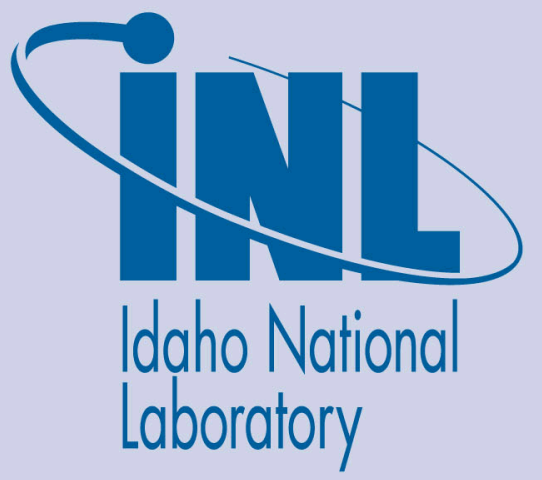




\section{DISCLAIMER}

This information was prepared as an account of work sponsored by an agency of the U.S. Government. Neither the U.S. Government nor any agency thereof, nor any of their employees, makes any warranty, expressed or implied, or assumes any legal liability or responsibility for the accuracy, completeness, or usefulness, of any information, apparatus, product, or process disclosed, or represents that its use would not infringe privately owned rights. References herein to any specific commercial product, process, or service by trade name, trade mark, manufacturer, or otherwise, does not necessarily constitute or imply its endorsement, recommendation, or favoring by the U.S. Government or any agency thereof. The views and opinions of authors expressed herein do not necessarily state or reflect those of the U.S. Government or any agency theof. 
INL/EXT-19-55295

Revision 0

\section{Out-of-pile performance of High Temperature Irradiation Resistant and Cladding Thermocouples}

Richard Skifton, Lance Hone, Joe Palmer ${ }^{1}$

Ember Sikorski, Scott Riley, Brian Jaques, Lan Li ${ }^{2}$

August 2019

Idaho National Laboratory C670 Measurement Sciences

Idaho Falls, Idaho 83415

http://www.inl.gov

Prepared for the

U.S. Department of Energy

Office of Nuclear Energy

Under DOE Idaho Operations Office

Contract DE-AC07-05ID14517 



\title{
C670 Measurements Sciences
}

\section{Out-of-pile performance of High Temperature Irradiation Resistant and Cladding Thermocouples}

\author{
INL/EXT-19-55295
}

Revision 0

August 2019

Approved by:

Title [optional]

Date

Name

Title [optional]

Date

Name

Title [optional]

Date

Name

Date

Title [optional] 



\begin{abstract}
The High Temperature Irradiation Resistant thermocouple (HTIR-TCs) has proven to be the nuclear temperature sensor. It outlast and outperforms all other commercially available thermocouples above $1100{ }^{\circ} \mathrm{C}$ inside reactor pressure vessels; also, recent calibration methods have pushed the HTIR-TC to accurately read temperatures through thermal transients during reactor shutdowns and restarts. The new temperature range of HTIR-TCs is from $0{ }^{\circ} \mathrm{C}$ to $1650{ }^{\circ} \mathrm{C}$. The main objective of this study is to address manufacturing a more robust TC for handling and inserting into reactor experiments; to also apply the TC to a wider application. The TC has shown to be mainly susceptible to oxygen levels inside the heat treatment and calibration process and it is recommended that $\mathrm{O}_{2}$ levels be brought to as low as possible. However, through modeling efforts the $\mathrm{O}_{2}$ has been found to intercalate only within the first few layers of niobium on the outer sheath. Lastly, multiple materials were used for the sheath and insulators; all with similar outcomes when testing occurred over a long period of time.
\end{abstract}




\section{CONTENTS}

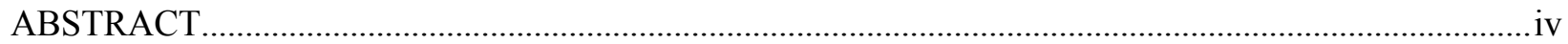

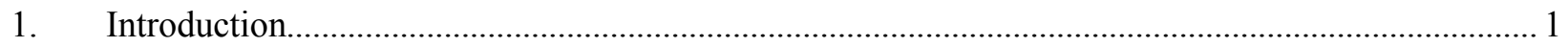

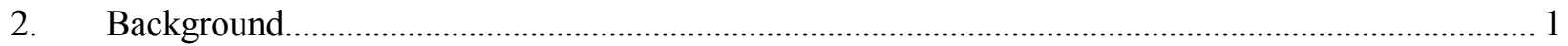

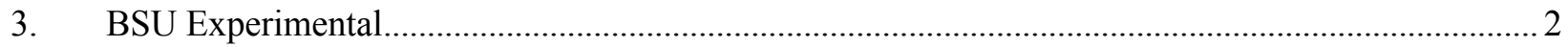

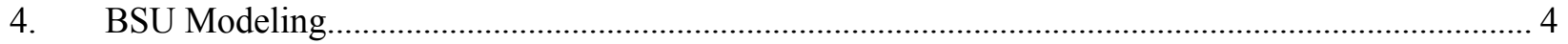

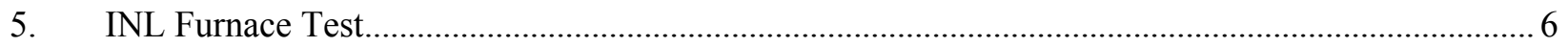

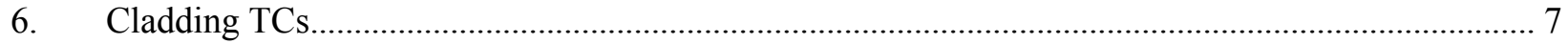

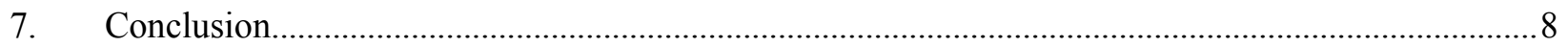




\section{ACRONYMS}

$\begin{array}{ll}\text { AGR } & \text { Advanced Gas Reactor } \\ \text { ATR } & \text { Advanced Test Reactor } \\ \text { BSU } & \text { Boise State University } \\ \text { EBSD } & \text { Electron Backscatter Diffraction } \\ \text { HTTL } & \text { High Temperature Test Laboratory } \\ \text { HTIR-TC } & \text { High Temperature Irradiation Resistant thermocouple } \\ \text { INL } & \text { Idaho National Laboratory } \\ \text { TC } & \text { Thermocouple }\end{array}$




\section{Out-of-pile performance of High Temperature Irradiation Resistant and Cladding Thermocouples}

\section{Introduction}

The High Temperature Irradiation Resistant thermocouple (HTIR-TCs) is the pinnacle of temperature sensing inside reactor vessels. They are sheathed thermocouples based on molybdenum and niobium alloys as sensing elements. The scope of this subtask is to improve the reliability of HTIR-TCs across a wider range of target operational parameters. The following are the main parameters to consider in the design optimization process: sensing elements alloy composition, sheath material composition, insulation material, and heat treatment process. Following common practice for commercial TCs, the objective is to define the most reliable instrument configuration and (if applicable) alternative options for sheath and insulation materials for different temperature ranges, starting from $1100{ }^{\circ} \mathrm{C}$ - the operational limit of commercial TCs in radiation environments - up to $1600^{\circ} \mathrm{C}$.

\section{Background}

The high temperature and radiation environment deep inside the core quickly de-calibrates all other thermocouple builds. How other commercially available thermocouples compare to the HTIR-TC can be seen in Table 1.

Table 1. Quality comparison of commercially available thermocouples and how they pair up to the HTIR-TC inside a high temperature radiation environment.

\begin{tabular}{|l|l|l|l|l|}
\hline Thermocouple & Type K & Type B & Type N & HTIR-TC \\
\hline Materials & $\begin{array}{l}\text { Chromel vs } \\
\text { Alumel }\end{array}$ & $\begin{array}{l}\text { PtRh } 30 \% \text { vs } \\
\text { PtRh } 6 \%\end{array}$ & Nicrosil vs. Nisil & $\begin{array}{l}\text { Molybdenum vs. } \\
\text { Niobium }\end{array}$ \\
\hline $\begin{array}{l}\text { Temperature } \\
\text { Range }\end{array}$ & $-270^{\circ} \mathrm{C}$ to $1260^{\circ} \mathrm{C}$ & $250^{\circ} \mathrm{C}$ to $1700^{\circ} \mathrm{C}$ & $-270^{\circ} \mathrm{C}$ to $1260^{\circ} \mathrm{C}$ & $0^{\circ} \mathrm{C}$ to $1700^{\circ} \mathrm{C}$ \\
\hline Cost & $\sim \$ 30 / \mathrm{ft}$ & $\sim \$ 250 / \mathrm{ft}$ & $\sim \$ 50 / \mathrm{ft}$ & $\sim \$ 250 / \mathrm{ft}$ \\
\hline $\begin{array}{l}\text { Radiation } \\
\begin{array}{l}\text { Tolerance as } \\
\text { Compared to } \\
\text { HTIR-TC }\end{array}\end{array}$ & $1 / 10^{\text {th }}$ & $\sim 1 / 100^{\text {th }}$ & $1 / 4^{\text {th }}$ & \\
\hline
\end{tabular}

The HITR-TC has been monitored over the last 1.5 years inside the Advanced Gas Reactor (AGR) 5/6/7 tests currently being performed at the Advanced Test Reactor (ATR) located at the remote site of Idaho National Laboratory (INL). The overwhelming success of the HTIR-TC in this experiment is staggering. The HTIR-TC has successfully measured $1500{ }^{\circ} \mathrm{C}$ for $\sim 9$ months; with intermittent shut down and restarts of the reactor putting the thermocouples through drastic thermal gradients. During such times the HTIR-TC has not only successfully measured the extreme high temperatures, but the low coolant (e.g. water) temperatures as well. Figure 1a shows the positioning of the various thermocouples inside Capsule 3 of the AGR 5/6/7 test; with about half as HTIR-TCs, while the other half are of a Type N construction. Specifically looking at TC-3-5, a HTIR-TC at the geometric center of the experiment, it can be seen in Figure $1 \mathrm{~b}$ measuring $\sim 1500{ }^{\circ} \mathrm{C}$ during reactor operation. This is the hottest, sustained temperature ever recorded inside a reactor. Further, the ATR has on average 10x more fluence than any commercial reactor; justifying the incredible nature of this new temperature sensor. 
(a)

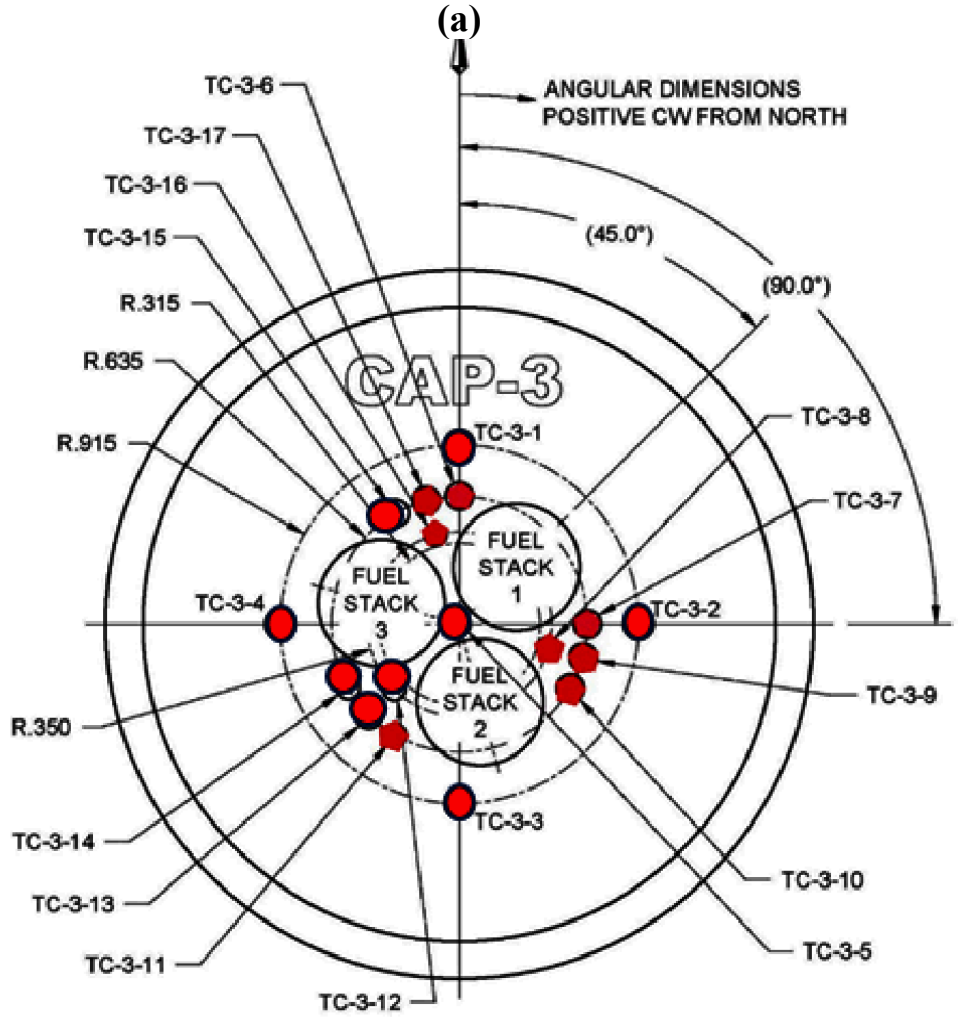

CAPSULE 3

(b)

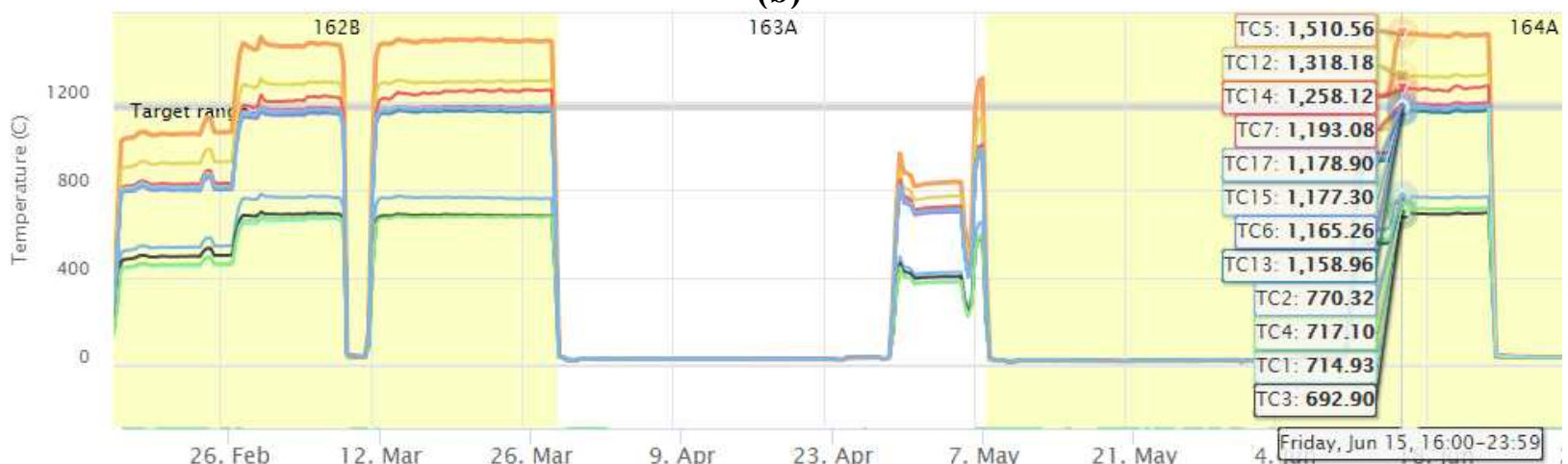

Figure 1. (a) Map of thermocouple positions inside capsule 3 of the AGR 5/6/7 experiment. (b) Measured temperatures over a period of time of the AGR 5/6/7 experiment with HTIR-TC matching the Type $N$ thermocouple readings in the periphery of the experiment, and outperforming all others at the geometric center.

\section{Experimental Work Performed at Boise State University}

The heat treatment of the HTIR-TC thermoelements (e.g. niobium and molybdenum) is necessary to move all the as-manufactured wire (state A) to the heat treated condition (state B). This dampens out any potential drifting during operation. In order to maintain ductility of the HTIR-TC after the extensive heat treatment and calibration process, Boise State University (BSU) has performed heat treatments at various temperatures with the HTIR-TC under two different sheathing materials. The experiment design can be seen in Table 2 with temperature ranging from no heat cycle up to $1600{ }^{\circ} \mathrm{C}$ for 24 hours. Afterwards the HTIR-TC samples were placed in a 3-point bending apparatus and the effective stress vs. effective strain was measured. 
Table 2. Experiment design for down-selecting ductile sheathing material after heat treatment and calibration.

\begin{tabular}{|l|l|l|l|l|}
\hline $\begin{array}{l}\text { HTIR-TC } \\
\text { Sheathing } \\
\text { Material }\end{array}$ & $\begin{array}{l}\text { No Heat } \\
\text { Treatment }\end{array}$ & $\begin{array}{l}1450 \text { C for } 6 \\
\text { hours }\end{array}$ & $\begin{array}{l}1600 \mathrm{C} \text { for } 6 \\
\text { Hours }\end{array}$ & $\begin{array}{l}1600 \mathrm{C} \text { for } 24 \\
\text { Hours }\end{array}$ \\
\hline Pure Nb Sheath & $\mathrm{x}$ & $\mathrm{x}$ & $\mathrm{x}$ & $\mathrm{x}$ \\
\hline Nb $1 \% \mathrm{Zr}$ & $\mathrm{x}$ & $\mathrm{x}$ & $\mathrm{x}$ & $\mathrm{x}$ \\
\hline
\end{tabular}

(a)
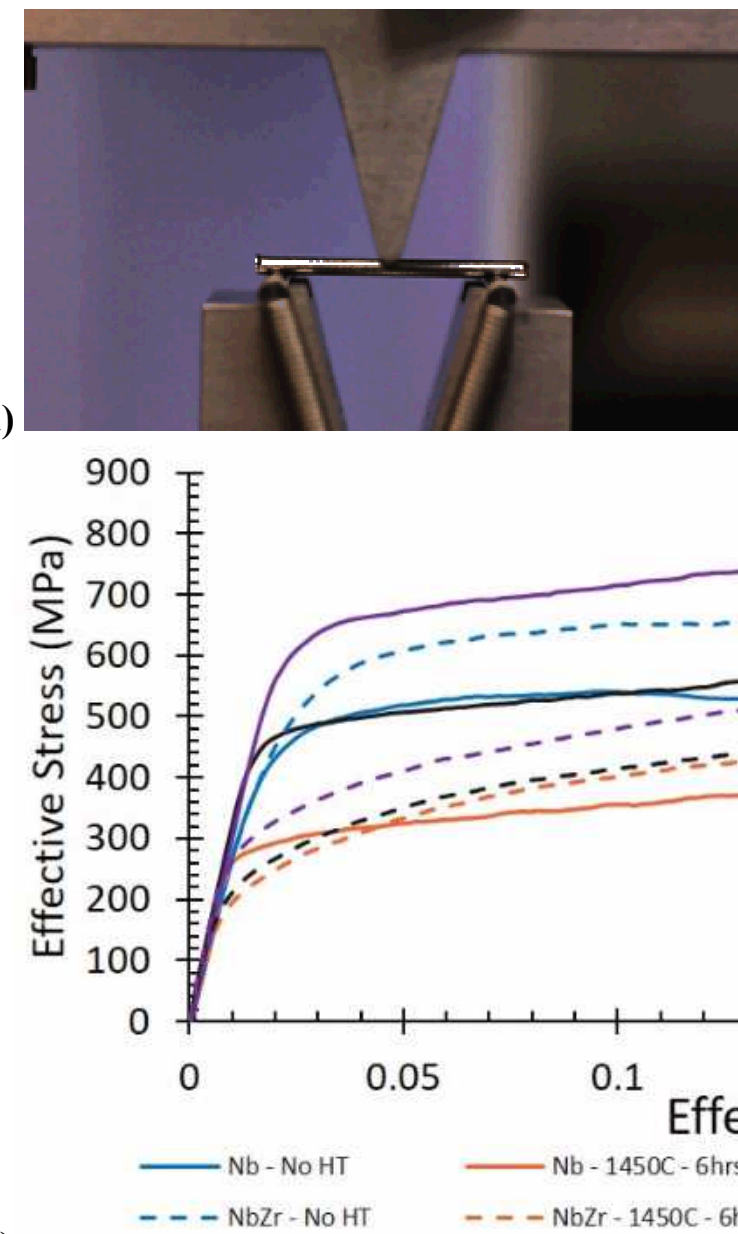

(b)
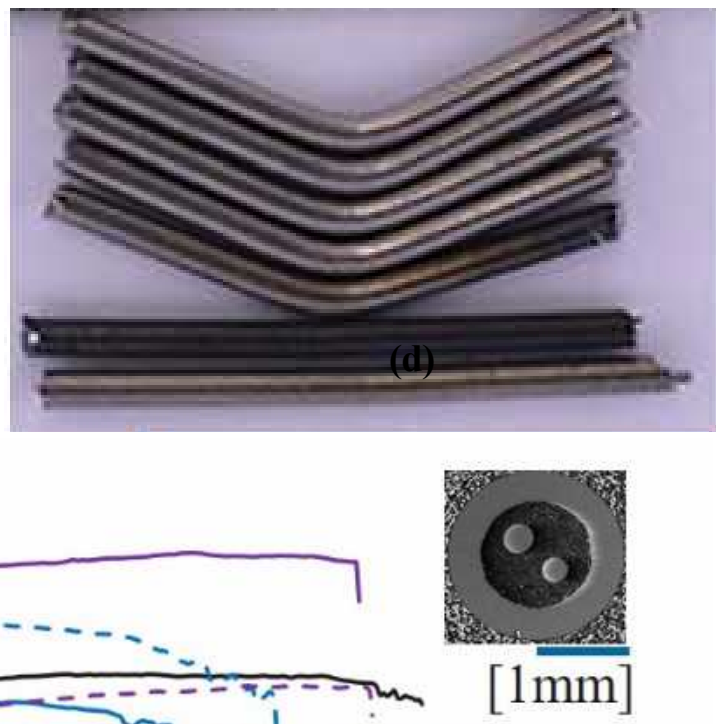

$[1 \mathrm{~mm}]$

\section{(c)}

Figure 2. (a) pre-test set up of 3-point bending being performed on HTIR-TC samples. (b) Bend test samples after the 3-point bend test. (c) Effect stress vs. Effective Strain outcome of each sample tested in the 3-point bend test. (d) Typical cross section of the HTIR-TC.

In regard to the ductility of the $\mathrm{TC}$, the effective percent total elongation, $\%$, of each test sample was then plotted vs. the respective heat treatment temperatures as seen in Figure 3. This shows that heat 
treating the HTIR-TC for 6 hours at $1600{ }^{\circ} \mathrm{C}$ is a sufficient heat soak.

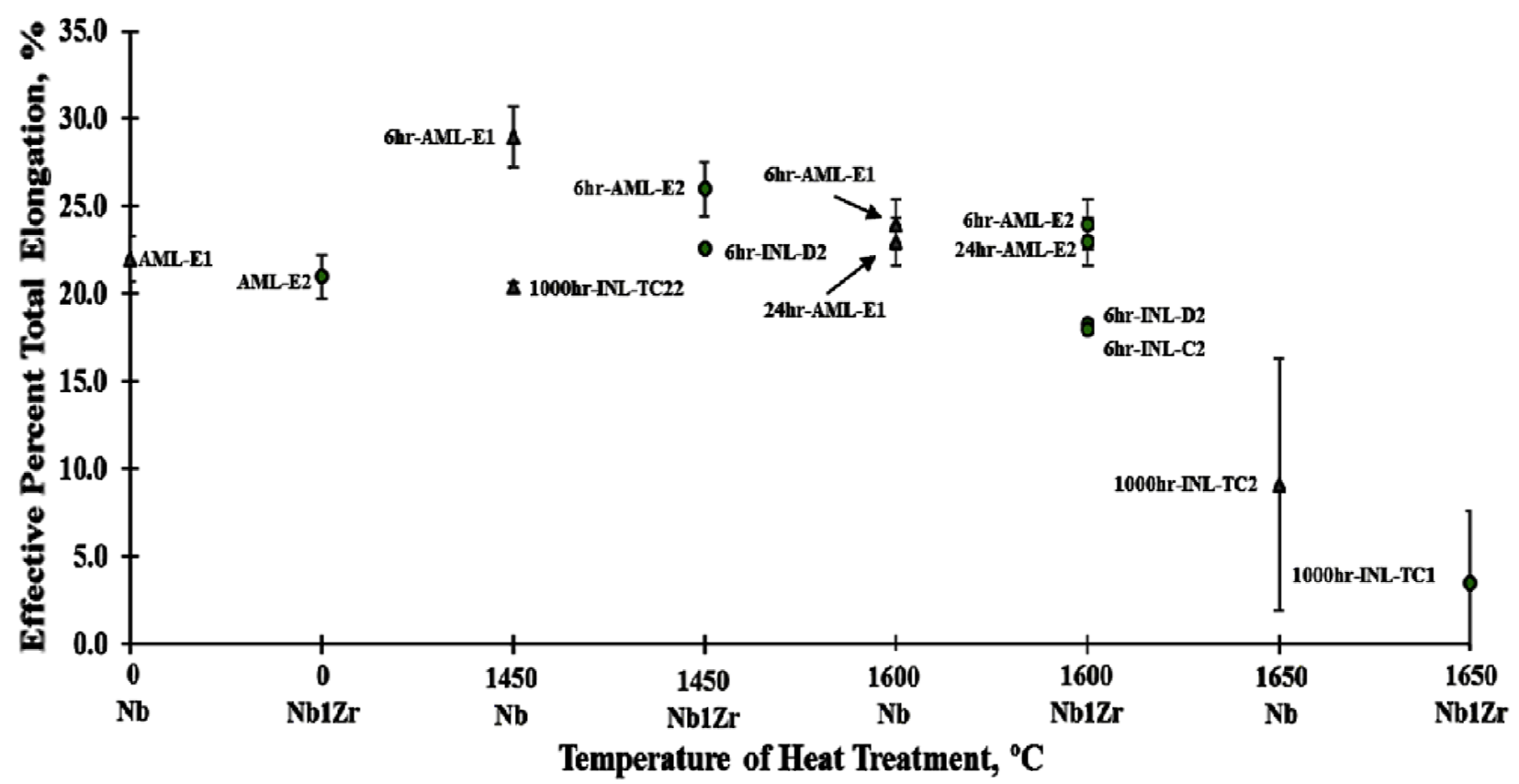

Figure 3. Effective percent total elongation for AML and INL heat treated HTIR-TCs showing $1600{ }^{\circ} \mathrm{C}$ for 6 hours is sufficient for heat treating time and temperature.

\section{Modeling Work Performed at Boise State University}

To better understand possible causes of drift in HTIR-TC performance, computational modeling is being performed. The goal is to first validate the modeling method with experiment and then extend the method to predict the effects of various heat treatments, dopants, oxygen and hydrogen uptake, and fission products.

A 3-step method is under development correlate structural changes with resultant voltage. The process begins with atomistic-scale modeling using Density Functional Theory on the HTIR-Mo and HTIR-Nb materials. Each consists of a 128-atom supercell including one La and one O atom for HTIR Mo and one $\mathrm{P}$ and one $\mathrm{O}$ atom for HTIR Nb. Once the geometry of each cell has been optimized, the electronic structure is calculated. The electronic structure, in turn, is used to calculate the absolute voltage the respective leg of the TC will produce. In summary, the method consists of:

Step 1. Optimize atomic structure

Step 2. Use atomic structure to calculate electronic structure

Step 3. Use electronic structure to calculate the Seebeck coefficient and integrate for voltage The first iteration, referred to in Figures 4 and 5 as method 1, only considered temperature during Step 3 when the Seebeck coefficient was integrated. Method 1 worked well for HTIR Mo as shown in Figure 4, but poorly for HTIR Nb. This suggests that HTIR Mo maintains the same structure with increasing temperature, while HTIR Nb undergoes structural change with increasing temperature. A second process, method 2, was developed in which Step 1 considers the effects of temperature, using Ab initio molecular dynamics. In method 2, the atomic structure is calculated at each temperature and the voltage will be evaluated for only that temperature. While method 2 is still in progress, the improvement of using the 300 ${ }^{\circ} \mathrm{K}$ HTIR Nb structure integrated over the full temperature range is shown in Figure 5. It is expected that as the higher temperature atomic structures are incorporated, the modeled voltage will better match the experimental voltage. 


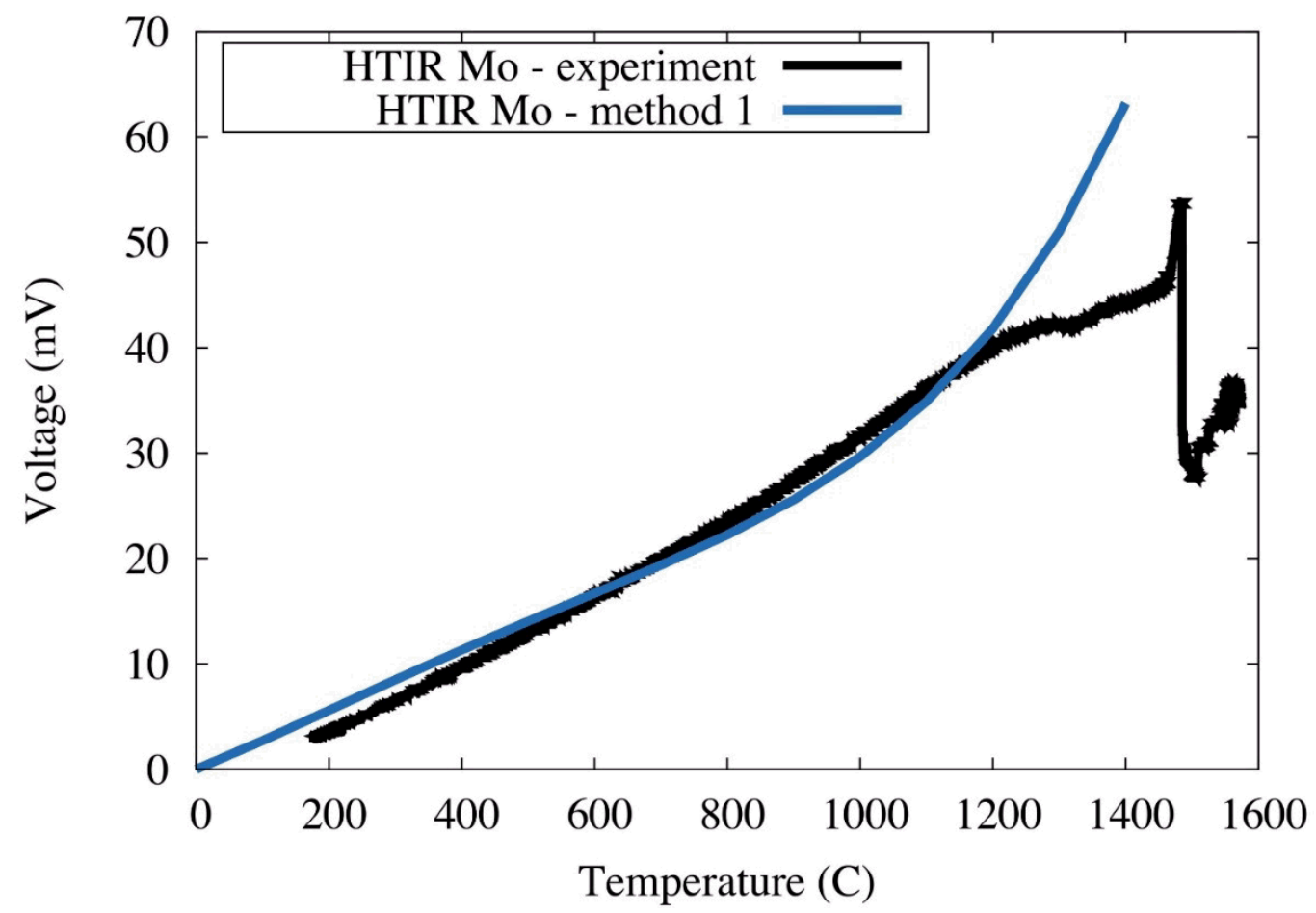

Figure 4. Comparison of HTIR-Mo voltage from modeling results following method 1, where temperature effects are not considered during atomic structure calculation, to experimental data. The experimental voltage was taken by pairing a HTIR Mo leg with the industry standard Pt leg and subtracting out the Pt contribution.

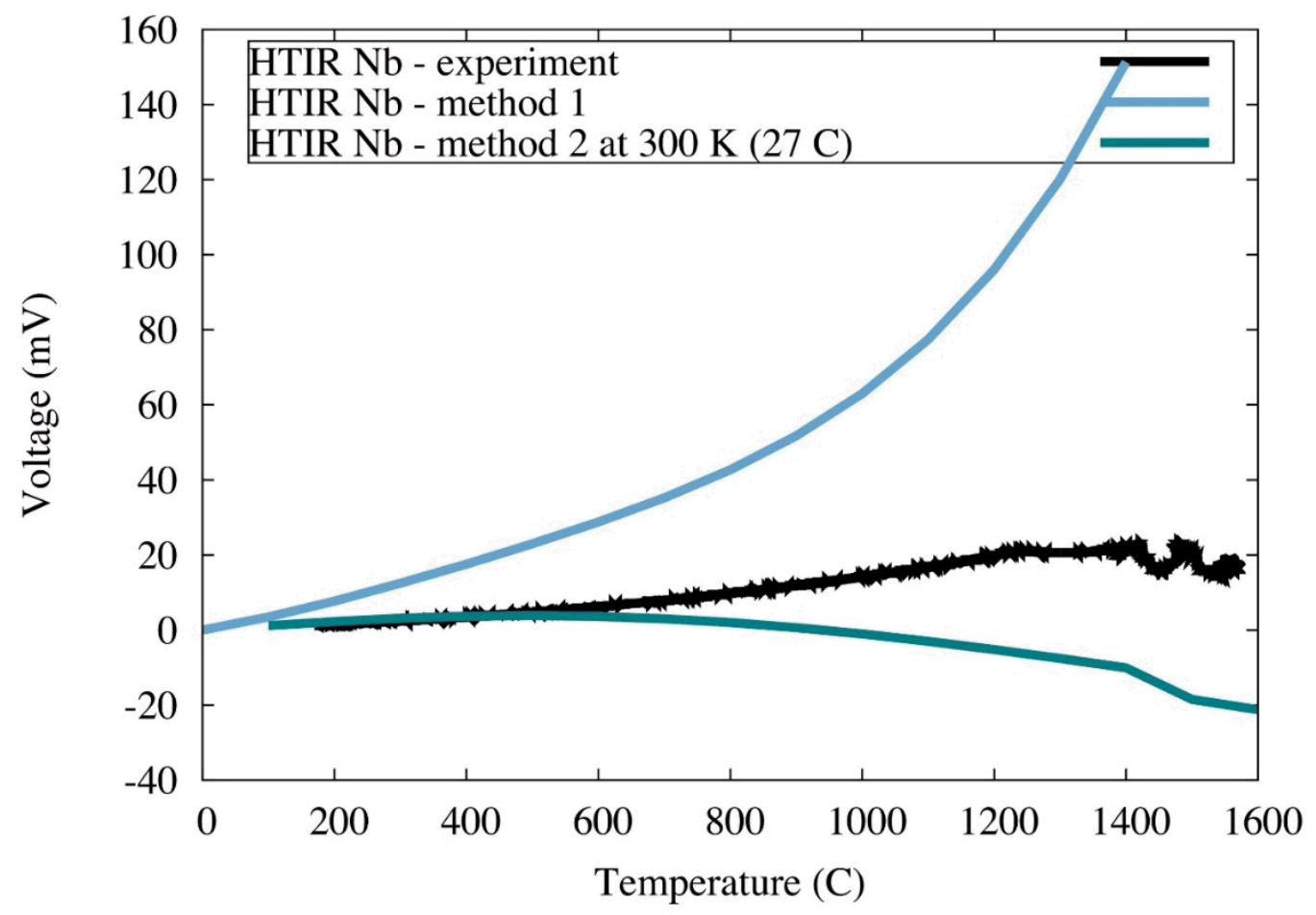

Figure 5. Comparison of HTIR-Nb voltage from modeling and experiment. Method 1 does not consider temperature effects during atomic structure calculation. Method 2 does consider temperature effects during atomic structure calculation. The experimental voltage was taken by pairing a HTIR-Nb leg with the industry standard Pt leg and subtracting out the Pt contribution. 
One potential cause if drift is the incorporation of oxygen. Electron Backscatter Diffraction (EBSD) data suggests that after heating, oxygen may enter the HTIR Nb thermoelement. Preliminary Ab initio Molecular Dynamics runs were performed towards a better understanding of how likely oxygen diffusion into the HTIR Nb is (Figure 6). However, these runs incorrectly predict that oxygen does not diffuse into the $\mathrm{Nb}$ surface. This is likely the result of the boundary conditions applied to the simulation, in which the unit cell is repeated infinitely in each direction. Thus, the calculations show that if there is one oxygen atom to every four surface $\mathrm{Nb}$ atoms and if every oxygen atom must behave the same way, the oxygen will not penetrate the surface. Further calculations will be conducted with unit cells with greater surface area and more oxygen atoms to get a more accurate look at the diffusion mechanism.

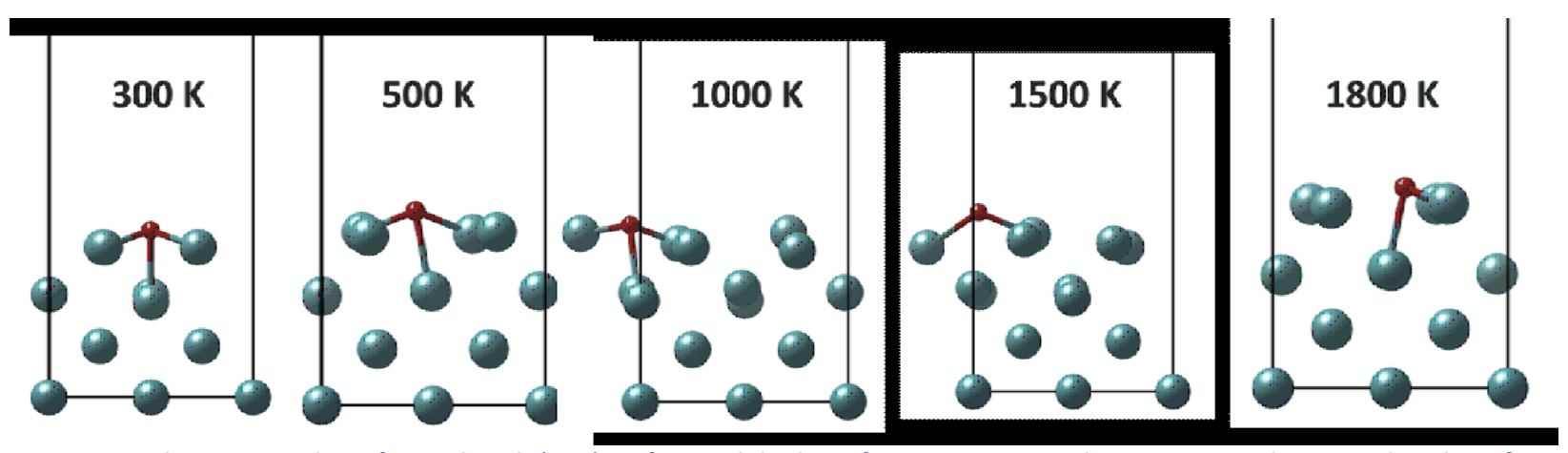

Figure 6. Preliminary studies of $\mathrm{O}$ at the $\mathrm{Nb}(100)$ surface. While these figures suggest $\mathrm{O}$ does not intercalate into the $\mathrm{Nb}$ surface, this is likely the result of inappropriate boundary conditions. Further work is underway to improve the models.

\section{Idaho National Laboratory Furnace Testing}

As part of broadening the HTIR-TC applicability as a low cost alternative to replace other commercially available TCs at their absolute maximum temperature (i.e. Type $\mathrm{K}$ and $\mathrm{N}$ both at $1260{ }^{\circ} \mathrm{C}$ and Type B at $\sim \$ 250 / \mathrm{ft}$, to date), the HTIR-TC was built with alumina, magnesia, and hafnia insulators inside a niobium with $1 \%$ zirconium sheath. Where other thermoelements begin to quickly drift away from their calibrated values, the HTIR-TC is performing exceptionally well at $1260{ }^{\circ} \mathrm{C}$. As can be seen in Figure 7, even after $\sim 1500$ hours the three different HTIR-TC builds are still within $0.4 \%$ of the furnace set point. Note: These values have been normalized as it was found a calibration using both room and boiling water temperature as a data point was needed. It appears that Magnesia (i.e. MgO), although had minimal drift for several months began to drift quite considerably after about 3-4 months. MgO insulation was the worst performer. This means that the HTIR TC is compatible with most common utilized oxides as insulators, therefore the sheathing material can be changed out for a non-oxidizing material. This potentially makes the HTIR-TC capable of most high temperature applications - not just nuclear. However, it is recommended for nuclear applications to use either pure niobium or niobium $1 \%$ zirconium sheathing with an alumina insulating layer. This is due to the performance of $\mathrm{MgO}$ in the outof-pile testing and hafnia becoming highly activated after previously performed in-pile tests. 
Table 3. Summary of HTIR-TC out-of-pile performance at $1250^{\circ} \mathrm{C}$ furnace set point.

\begin{tabular}{|c|c|c|c|}
\hline TC ID & Construction Details & Performance Summary & Ultimate Fate \\
\hline HTIR-TC-62 & $\begin{array}{l}\text { Al2O3 insulation, } \\
\mathrm{Nb} / 1 \% \mathrm{Zr} \text { sheath. La- } \\
\mathrm{Mo} / \mathrm{P}-\mathrm{Nb} \\
\text { thermoelements. } \\
1600{ }^{\circ} \mathrm{C} \text { heat treat for } \\
6 \mathrm{hrs} \text {. Mo protective } \\
\text { sleeve. }\end{array}$ & $\begin{array}{l}\text { Read about } 54{ }^{\circ} \mathrm{C} \text { high } \\
\left(1294{ }^{\circ} \mathrm{C}\right) \text { upon initial } \\
\text { startup with hot block at } \\
1250{ }^{\circ} \mathrm{C} \text {. Drifted up about } \\
4{ }^{\circ} \mathrm{C} \text { over next } 6 \text { weeks. } \\
\text { Insulation resistance was } \\
\text { initially about } 7000 \text { ohms } \\
\text { and increased to about } \\
25000 \text { ohms. }\end{array}$ & $\begin{array}{l}\text { As of } 8 / 27 / 2018 \text { reading } \\
1298{ }^{\circ} \mathrm{C} \text {. So the drift has } \\
\text { been minimal since } \\
\text { startup. } 9 / 17 / 18=1300 \\
{ }^{\circ} \mathrm{C} .9 / 24 / 2018=1301.5{ }^{\circ} \mathrm{C} \\
11 / 20 / 18=1317{ }^{\circ} \mathrm{C} \\
12 / 19 / 18=1321.7{ }^{\circ} \mathrm{C} \\
1 / 30 / 19=1326.3^{\circ} \mathrm{C} \\
7 / 22 / 19=1284{ }^{\circ} \mathrm{C} .\end{array}$ \\
\hline HTIR-TC-64 & $\begin{array}{l}\text { Same as TC-62 except } \\
\text { MgO insulation }\end{array}$ & $\begin{array}{l}\text { Read about } 38^{\circ} \mathrm{C} \text { low } \\
\left(1212^{\circ} \mathrm{C}\right) \text { upon initial } \\
\text { startup with Hot block at } \\
1250{ }^{\circ} \mathrm{C} \text {. Drifted up about } \\
2{ }^{\circ} \mathrm{C} \text { over the next } 6 \\
\text { weeks. Insulation } \\
\text { resistance was initially } \\
\text { about } 40 \text { ohms and } \\
\text { gradually increased to } \\
\text { about } 140 \text { ohms. } 40 \\
\text { ohms is sure low, but it } \\
\text { doesn't seem to be } \\
\text { affecting the reading } \\
\text { much and it did increase } \\
\text { as the test progressed. }\end{array}$ & $\begin{array}{l}\text { As of } 8 / 27 / 2018 \text { reading } \\
1214{ }^{\circ} \mathrm{C} \text {. So the drift has } \\
\text { been virtually nil since } \\
\text { startup. } 9 / 17 / 18=1210.5 \\
{ }^{\circ} \mathrm{C} .9 / 24 / 2018=1211.5{ }^{\circ} \mathrm{C} \\
11 / 20 / 18=1196{ }^{\circ} \mathrm{C} \\
12 / 19 / 18=1182{ }^{\circ} \mathrm{C} \\
1 / 30 / 19=1173{ }^{\circ} \mathrm{C} \\
\text { No chart readings after } \\
1 / 30 / 2019 \text { although } \\
\text { resistances still look } \\
\text { good. It had drifted a lot } \\
\text { by the time of the last } \\
\text { reading. }\end{array}$ \\
\hline HTIR-TC-66 & $\begin{array}{l}\text { Same as TC-62 except } \\
\text { HfO2 insulation }\end{array}$ & $\begin{array}{l}\text { Read about } 54{ }^{\circ} \mathrm{C} \text { low } \\
\left(1196^{\circ} \mathrm{C}\right) \text { upon initial } \\
\text { startup with Hot block at } \\
1250{ }^{\circ} \mathrm{C} \text {. Stayed } \\
\text { essentially dead flat over } \\
\text { the next } 6 \text { weeks. } \\
\text { Insulation resistance was } \\
\text { initially about } 230 \text { ohms } \\
\text { and gradually increased } \\
\text { to about } 270 \text { ohms. }\end{array}$ & $\begin{array}{l}\text { As of } 8 / 27 / 2018 \text { reading } \\
1197{ }^{\circ} \mathrm{C} \text {. No drift since } \\
\text { startup. It's easier to } \\
\text { solve calibration errors } \\
\text { than drift problems so } \\
\text { this is promising. } \\
9 / 17 / 18=1197.5^{\circ} \mathrm{C} \text {. } \\
9 / 24 / 2018=1195.5^{\circ} \mathrm{C} \\
11 / 20 / 18=1201{ }^{\circ} \mathrm{C} \\
12 / 19 / 18=1207{ }^{\circ} \mathrm{C} \\
1 / 30 / 19=1208{ }^{\circ} \mathrm{C} \\
3 / 26 / 19=1198{ }^{\circ} \mathrm{C} \\
5 / 7 / 19=1184{ }^{\circ} \mathrm{C} \text {. } \\
\text { Failed } 5 / 9 / 2019 . \text { It did } \\
\text { very well. }\end{array}$ \\
\hline
\end{tabular}




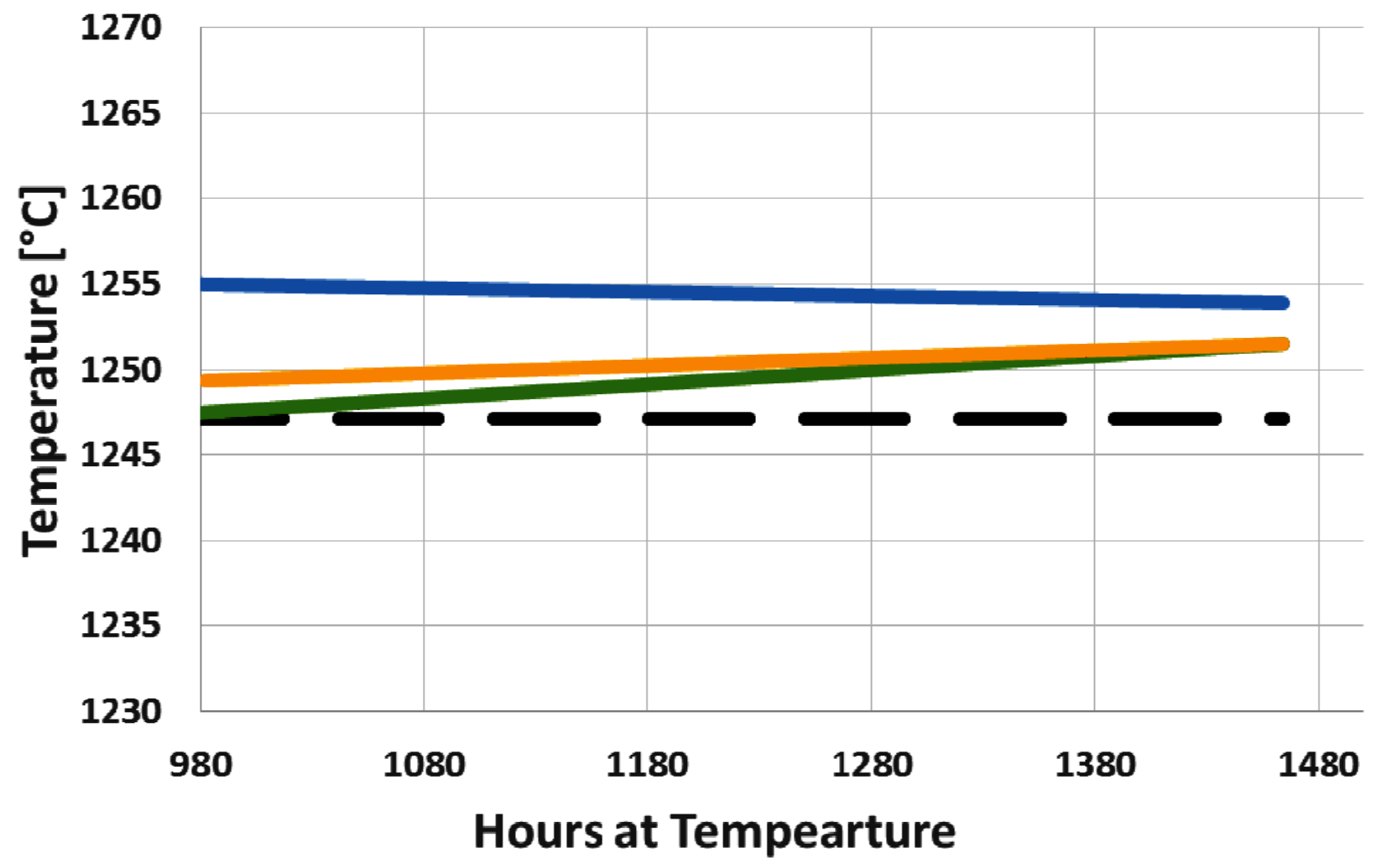

Twell $\longrightarrow$ TC 62 - Alumina

TC 64 - Magnesia

TC66 - Hafnia

Figure 7. Longevity tests of various HTIR-TC builds at $1250{ }^{\circ} \mathrm{C}$. Notice the HTIR-TCs are within $0.4 \%$ of set point temperature after $\sim 1500$ hours of testing. These temperatures have been normalized to the furnace thermal well temperature.

\section{Cladding Thermocouples}

Attaching TCs to nuclear fuel cladding proves most effective when a strong material bond can be formed between the heat source and at or near the thermocouple junction using welding techniques. The main benefits of this attachment type are for temperature measurements requiring high accuracy and time response in targeted areas. Other strategies for measuring temperature with thermocouples include using tie wire to wrap TCs against an area of interest, using spring clips to press a TC against a sample, attaching with epoxies or cements, suspending a TC in a steady state environment, etc. However, these methods are inferior in performance when a need for fast and accurate data is desired while measuring nuclear fuel cladding.

Welding the TCs to nuclear fuel cladding required considerations for material types, cladding and sheath thickness, TC orientation, and other minor components. Concerning material selection, the welding of common alloys used for nuclear fuel cladding can result in increased brittleness and variations in hardness (at the joint) as a result of the formation of hydrides, intermetallic phases, and the $\alpha \rightarrow \beta$ phase transition. This is especially noticeable when welding dissimilar materials (i.e. sheath-to-cladding or wireto-cladding). Therefore, TC sheath material choices were made based on commonalities between metals while still providing their essential function.

Originally, these attachments were to be done using laser welding, but when considering minimal cladding thickness and sheath thickness, low energy welds were required. This was obtained using a relatively new welding system by Sunstone Engineering called Orion $200 \mathrm{i}^{2}$ system. This welding system utilizes a $1 \mathrm{~mm}$ diameter tungsten electrode, which facilitates the formation of an arc to the grounded work piece. The arc produced generates the heat necessary to fuse components while the system also provides an argon cover gas to the welding location for the duration of the arc-pulse. This micro-arc 
welding system is capable of delivering an arc-pulse at energy levels more favorable for small diameter sheathed thermocouples.

$\mathrm{TC}$ orientation proves to be of significant importance. When attaching the end of a TC perpendicular, or normal, to the cladding, accuracy severely decreases when compared to a paraxial attachment where the $\mathrm{TC}$ is attached axially along the cladding surface.

(a)

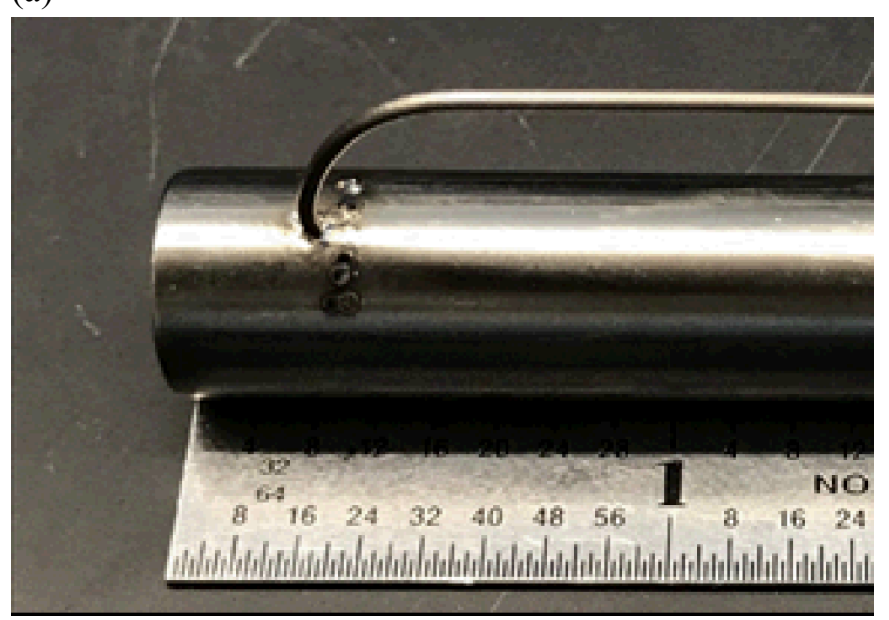

(b)

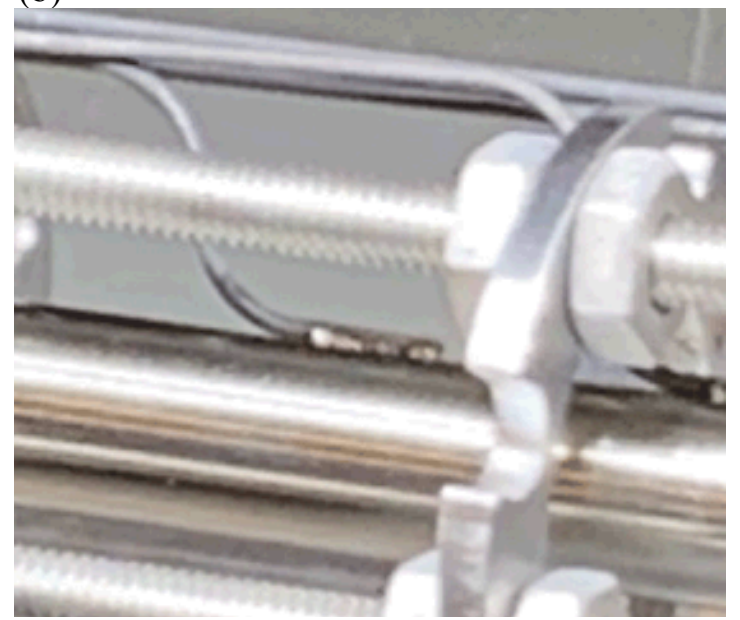

Figure 8. (a) Perpendicular ( $\perp$ ) thermocouple orientation and (b) paraxial (II) orientation

This can be seen below from data collected in an out-of-pile experiment using an electric heater cartridge placed inside a cladding tube. This experiment was performed by pulsing the heater cartridge in a manner that simulates a potential transient reactor test to evaluate the response from different thermocouple orientations. 


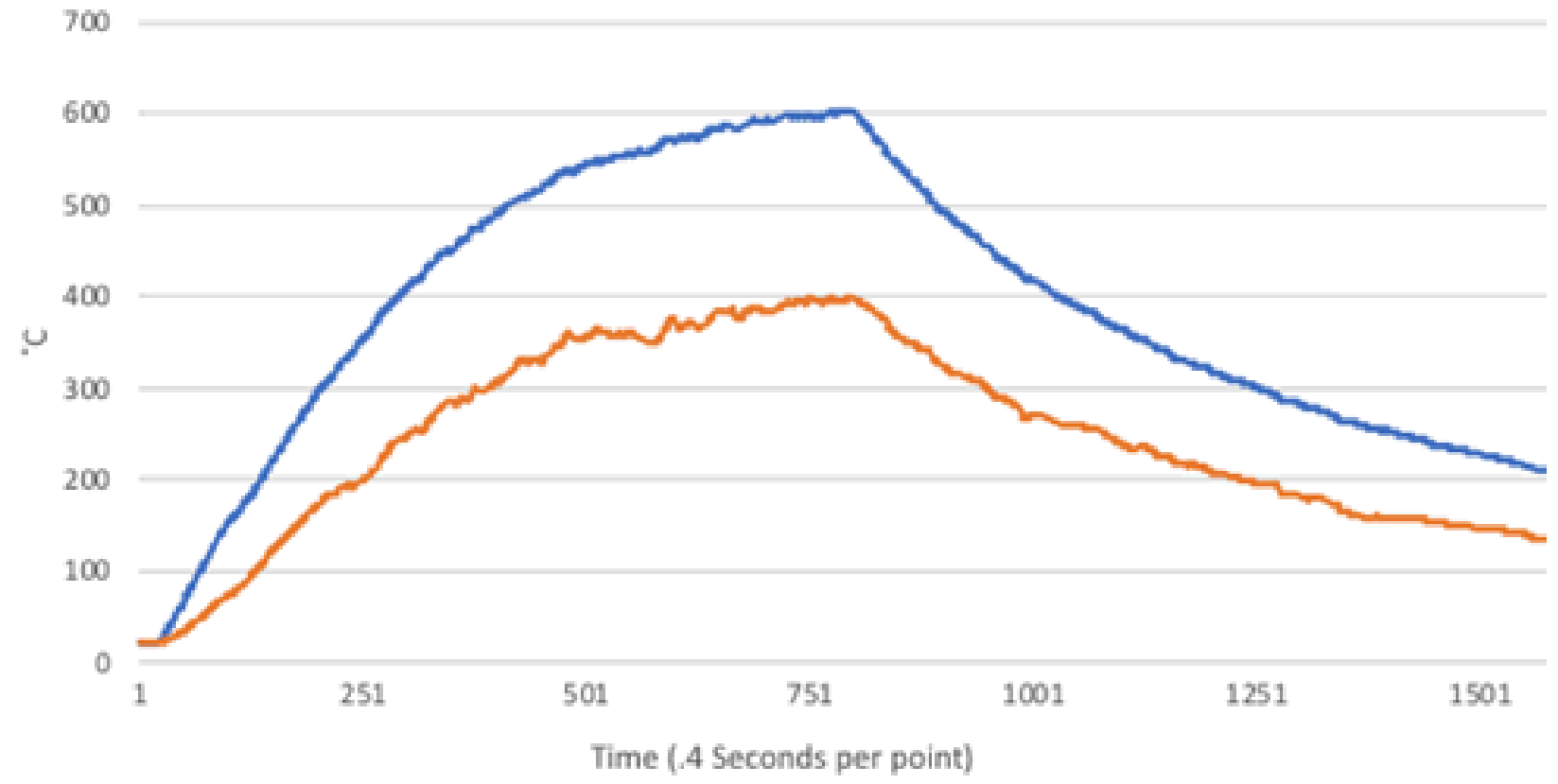

-TC 1 Parallel Attachment - TC 2 Normal Attachment

Figure 9. Recorded temperatures during an electrically heated pulse test

At the High Temperature Test Laboratory (HTTL) at the INL, TC attachment methods have been developed and studied in many different combinations such as grounded TCs, ungrounded TCs, various TC sheath materials, filler metal attachments, wire-to-cladding attachments with an intrinsic junction, and various $\mathrm{TC}$ types (type $\mathrm{K}$, type $\mathrm{R}$, type $\mathrm{C}$, etc.) completed to support scenarios that can prove useful for measuring cladding temperatures with TCs.

\section{Conclusion}

The HTIR-TC is the world's leading nuclear thermocouple. Achieving higher temperatures with longevities no other thermocouple has been able to achieve deep inside the reactor core. From the various builds and tests performed in this study, it is recommended that for nuclear applications a pure niobium sheath with alumina insulating layer be used. For other applications, the molybdenum and niobium thermoelements have shown to withstand high temperatures with other insulators and sheaths. 